\title{
Effect of Different Seed Rate and Spacing on Yield and Economics of Ginger (Zingiber officinale Rosc) Cultivation
}

\author{
Nilanjana Datta ${ }^{1 *}$, D.K. Ghosh ${ }^{1}$ and Tapas Sarkar ${ }^{2}$ \\ ${ }^{1}$ Department of Spices and Plantation Crops, ${ }^{2}$ Department of Fruits and Orchard Management, \\ Faculty of Horticulture, Bidhan Chandra Krishi Viswavidyalaya (Agricultural University), \\ Mohanpur-741252, Nadia, West Bengal, India \\ *Corresponding author
}

\begin{tabular}{|c|c|}
\hline \multicolumn{2}{|c|}{ A B S T R A C T } \\
\hline & The experiment was carried out with the aim to study on the effect of different seed rate \\
\hline $\begin{array}{l}\text { Ke y w o r d s } \\
\text { Ginger, Seed rate, } \\
\text { Spacing, Yield, } \\
\text { Economy. }\end{array}$ & $\begin{array}{l}\text { and spacing on yield of ginger. The experiment was carried out at the Horticultural } \\
\text { Research Station, Mondouri, Bidhan Chandra Krishi Viswavidyalaya, Mohanpur, Nadia, } \\
\text { and West Bengal during the year } 2013-14 \text { and } 2014-15 \text {. The variety 'cv. Gorubathan' was } \\
\text { used under the study. These experiment shows that among the five different spacing ( } 20 \times 1 \\
15 \mathrm{~cm}, 20 \times 20 \mathrm{~cm}, 25 \times 20 \mathrm{~cm}, 25 \times 25 \mathrm{~cm} \text { and } 30 \times 20 \mathrm{~cm} \text { ) and two seed rhizome size }\end{array}$ \\
\hline Article Info & $\begin{array}{l}(20 \mathrm{~g} \text { and } 30 \mathrm{~g}) \text {, increasing trend in yield per plant was observed with increase in spacing. } \\
\text { The plants raised from the bigger seed rhizome }(30 \mathrm{~g}) \text { produced bigger clump } 276.13 \mathrm{~g} \text {. In }\end{array}$ \\
\hline $\begin{array}{l}\text { Accepted: } \\
\text { 17 July } 2017 \\
\text { Available Online: } \\
\text { 10 September } 2017\end{array}$ & $\begin{array}{l}\text { case of interaction effect, closest spacing }(20 \times 15 \mathrm{~cm}) \text { in combination with bigger seed } \\
\text { rhizome }(30 \mathrm{~g}) \text { produced highest yield per ha of } 13.95 \mathrm{t} \text { and } 11.04 \mathrm{t} \text {. It was observed that } \\
\text { maximum cost of cultivation were recorded (Rs. } 104,312 /-) \text { and }(\text { Rs. } 101146 /-) \text { in both the } \\
\text { year respectively with } 20 \times 15 \mathrm{~cm} \text { spacing and } 30 \mathrm{~g} \text { seed size. The benefit: cost ratio was highest } \\
\text { in } \mathrm{P}_{5} \mathrm{~S}_{1}(2.16 \text { and } 2.29) \text { followed by } \mathrm{P}_{4} \mathrm{~S}_{1}(2.12 \text { and } 2.27) \text { in the respective years. }\end{array}$ \\
\hline
\end{tabular}

\section{Introduction}

Ginger (Zingiber officinale Rosc) is widely used in food, beverage, confectionery and medicine. It is valued in medicine as a carminative and stimulant of gastro intestinal tract. Dry ginger is used for the manufacture of oil, oleoresin, essence, soft drinks etc. India is the largest producer, consumer and exporter of ginger in the world. The size of planting materials and spacing are among the major factors influencing growth, yield and economics of ginger. Considering these the present investigation was undertaken to study the effect of different spacing and seed rate i.e. size of seed materials on yield and yield component and economics of ginger cultivation.

\section{Materials and Methods}

The experiment was carried out at H.R.S., Mondouri, Bidhan Chandra Krishi Viswavidyalaya, Nadia in two consecutive year (2013-14 and 2014-15). The experiment was laid out in split plot design with three replications. Five different spacing i.e. $\mathrm{P}_{1}(20$ x $15 \mathrm{~cm}) \mathrm{P}_{2}(20 \times 20 \mathrm{~cm}) \mathrm{P}_{3}(25 \times 20 \mathrm{~cm}), \mathrm{P}_{4}$ $(25 \times 25 \mathrm{~cm})$ and $\mathrm{P}_{5}(30 \times 25 \mathrm{~cm})$ as main plot and two seed rate (size of planting material) 
i.e. $\mathrm{S}_{1}(20 \mathrm{~g})$ and $\mathrm{S}_{2}(30 \mathrm{~g})$ as subplot treatments were included in this investigation. There were ten treatments combinations. Indofil-M $45(0.3 \%)$ treated rhizome (cv. Gorubathan) were planted in the middle of April during both the years. Fertilizers were applied @ 125: 100: 100 kg NPK / ha. Entire $\mathrm{P}$ with $1 / 2 \mathrm{~K}$ and $1 /{ }_{3} \mathrm{~N}$ along with FYM @ 20 $\mathrm{t} /$ ha were given as basal application. $1 /{ }_{3} \mathrm{~N}$ at 45 DAP and $1 /{ }_{3} \mathrm{~N}$ and $1 / 2 \mathrm{~K}$ were applied at 90 DAP followed by earthing up and mulching. The rhizome was harvested at 210 DAP. The observations on different parameters were recorded from five randomly selected plants per replication.

\section{Results and Discussion}

The clump weight increased from $225.33 \mathrm{~g}$ to $321.66 \mathrm{~g}$ and $188.50 \mathrm{~g}$ to $267.50 \mathrm{~g}$ with the increase in spacing from $20 \times 15 \mathrm{~cm}$ to $30 \mathrm{~cm}$ $\mathrm{x} 25 \mathrm{~cm}$ in the respective years, so, increasing trend in yield per plant, was observed with increase in spacing, decrease in plant population level. The plants raised from the bigger seed rhizome (30 g) produced bigger clump $276.13 \mathrm{~g}$ and $241.80 \mathrm{~g}$ in two respective years. The yield increased with seed rate (Mohanty et al., 1988). Among the interactions, maximum clump weight (350.66 g) was recorded in plants raised under widest spacing $(30 \times 25 \mathrm{~cm})$ coupled with bigger $(30$ g) rhizome $\left(\mathrm{P}_{5} \mathrm{~S}_{2}\right)$ in the $1^{\text {st }}$ year but minimum clump weight $(184.00 \mathrm{~g})$ was recorded in the $\mathrm{P}_{1} \mathrm{~S}_{1}(20 \mathrm{x} 15 \mathrm{~cm}, 20 \mathrm{~g})$ treatment combination in the $2^{\text {nd }}$ year. Data presented in table 2 revealed that maximum length of clump $21.03 \mathrm{~cm}$ was recorded under widest spacing $(30 \times 25 \mathrm{~cm})$ in the 1 st year. The longest $(22.40 \mathrm{~cm})$ clump was recorded from plant at widest spacing $(30 \times 25 \mathrm{~cm}) i$.e. less population in combination with bigger seed rhizome $(30 \mathrm{~g})$ in $1^{\text {st }}$ year. Maximum breadth was observed $14.80 \mathrm{~cm}$ under $30 \times 25 \mathrm{~cm}$ spacing with $30 \mathrm{~g}$ seed size in the $1^{\text {st }}$ year and $12.63 \mathrm{~cm}$ in the $2^{\text {nd }}$ year. Higher growth and yield were associated with greater size of planting material (Ghosh et al., 2008).

Higher length of finger was recorded with wider spacing during both the years of experiment. The maximum length of 10.75 $\mathrm{cm}$ and $10.68 \mathrm{~cm}$ and maximum breadth of $2.99 \mathrm{~cm}$ and $2.89 \mathrm{~cm}$ were recorded with $30 \mathrm{x}$ $25 \mathrm{~cm}$ spacing in the respective years (Table 3 ). Bigger seed rhizome produced the longer finger as compared to smaller one. In case of interaction effect $\mathrm{P}_{4} \mathrm{~S}_{2}(25 \times 25 \mathrm{~cm}, 30 \mathrm{~g})$ treatment produced the longest finger $(10.97$ $\mathrm{cm})$. Maximum breadth $(3.01 \mathrm{~cm})$ was observed in $\mathrm{P}_{5} \mathrm{~S}_{2}(30 \times 25 \mathrm{~cm}, 30 \mathrm{~g})$ treatment combination (Table 4). Such a difference in the production can be sought from sourcesink relationship in plant. Bigger size of planting material constitutes a stronger sink than the smaller one. Interaction effects of spacing and corm size indicated that $\mathrm{P}_{1} \mathrm{~S}_{2}(40$ $\mathrm{x} 40 \mathrm{~cm}, 500 \mathrm{~g}$ ) combination produced maximum yield per plot of $74.52 \mathrm{~kg}, 68.37 \mathrm{~kg}$ and $71.45 \mathrm{~kg}$ during the respective years (1998-2001) and pooled data as compared to minimum yield of $20.26 \mathrm{~kg}, 17.29 \mathrm{~kg}$ and $18.78 \mathrm{~kg}$ with $\mathrm{P}_{5} \mathrm{~S}_{1}(90 \mathrm{x} 85 \mathrm{~cm}, 300 \mathrm{~g})$ combination in the year 1999, 2000 and pooled data, respectively.

Hence, translocation and mobilization of assimilates and nutrients from the source are more, thereby produced superior fingers. Increasing trend in the weight of finger was noticed with increase in spacing up to certain limit. Yield increased linearly as the spacing reduced due to superior yield in the case of high plant populations over that of low plant population (Ghosh and Bandopadhya, 2008). The bigger size rhizome $(30 \mathrm{~g})$ recorded maximum weight $(66.35 \mathrm{~g})$ of finger. The bigger seed rhizome (30 g) coupled with $30 \mathrm{x}$ $25 \mathrm{~cm}$ spacing $\left(\mathrm{P}_{5} \mathrm{~S}_{2}\right)$ recorded the maximum weight of finger $(71.51 \mathrm{~g})$. These results are in good conformity with the observations of Korla et al., (1989), reported mean pseudo 
stem of 5.1,6.2,6.3 and 7.1 found from seed size of $5-10 \mathrm{~g}, 10-15 \mathrm{~g}, 15-20 \mathrm{~g}$ and $20-25 \mathrm{~g}$, respectively and also stated that mean yield of $33.3,65.4,79.7$ and $122.5 \mathrm{~g}$ per plant found from seed size of $5-10 \mathrm{~g}, 10-15 \mathrm{~g}, 15-20 \mathrm{~g}$ and 20-25g, respectively. Closer spacing might affect the growth and development of plants due to competition among them for nutrients and other resources available per unit area but under spacing above the optimum, the utilization of the land may be less and thereby the yield might have been reduced. These results are in good conformity with the observations of Singh et al., (2000).

Table.1 Effect of different spacing and seed rate on yield of ginger

\begin{tabular}{|c|c|c|c|c|c|c|c|c|}
\hline \multirow[t]{2}{*}{ Treatment } & \multicolumn{2}{|c|}{ Yield(t/ha) } & \multicolumn{2}{|c|}{ Yield (g/plant) } & \multicolumn{2}{|c|}{$\begin{array}{c}\text { Clump Length } \\
\text { (cm) }\end{array}$} & \multicolumn{2}{|c|}{$\begin{array}{c}\text { Clump Breath } \\
\text { (cm) }\end{array}$} \\
\hline & $1^{\text {st }} \mathrm{Yr}$ & $2^{\text {nd }} Y r$ & $1^{\text {st }} \mathbf{Y r}$ & $2^{\text {nd }} Y r$ & $1^{\text {st }} \mathbf{Y r}$ & $2^{\text {nd }} \mathrm{Yr}$ & $1^{\text {st }} \mathbf{Y r}$ & $2^{\text {nd }} \mathrm{Yr}$ \\
\hline$P_{1}(20 \times 15 \mathrm{~cm})$ & 13.74 & 10.88 & 225.33 & 188.50 & 18.92 & 17.98 & 11.71 & 11.50 \\
\hline$P_{2}(20 \times 20 \mathrm{~cm})$ & 11.38 & 10.22 & 229.83 & 210.16 & 19.21 & 18.30 & 13.11 & 11.88 \\
\hline $\mathbf{P}_{3}(25 \times 20 \mathrm{~cm})$ & 11.03 & 9.73 & 252.16 & 230.50 & 21.20 & 19.13 & 12.85 & 11.93 \\
\hline$P_{4}(25 \times 25 \mathrm{~cm})$ & 10.26 & 9.06 & 280.00 & 250.33 & 21.23 & 19.85 & 13.65 & 12.68 \\
\hline$P_{5}(30 \times 25 \mathrm{~cm})$ & 9.95 & 8.38 & 321.66 & 267.50 & 21.71 & 20.53 & 14.03 & 12.66 \\
\hline S.Em.( $( \pm)$ & 0.607 & 0.718 & 9.708 & 21.890 & 1.214 & 0.745 & 0.464 & 0.346 \\
\hline $\mathrm{CD}(\mathrm{P}=\mathbf{0 . 0 5})$ & 1.979 & NS & 31.657 & NS & NS & NS & 1.513 & NS \\
\hline $\mathrm{S}_{1}(20 \mathrm{~g})$ & 10.76 & 9.31 & 247.46 & 217.00 & 19.69 & 18.42 & 12.44 & 11.72 \\
\hline$S_{2}(30 \mathrm{~g})$ & 11.78 & 10.00 & 276.13 & 241.80 & 21.22 & 19.90 & 13.70 & 12.54 \\
\hline S.Em. ( \pm$)$ & 0.592 & 0.535 & 7.879 & 4.825 & 0.402 & 0.590 & 0.251 & 0.348 \\
\hline $\mathrm{CD}(\mathrm{P}=\mathbf{0 . 0 5})$ & 1.761 & 1.688 & 24.81 & 15.198 & 1.301 & NS & NS & NS \\
\hline
\end{tabular}

Table.2 Interaction effect of different spacing and seed rate on yield of ginger

\begin{tabular}{|c|c|c|c|c|c|c|c|c|}
\hline \multirow{2}{*}{ Treatment } & \multicolumn{2}{|c|}{ Yield (t/ha) } & \multicolumn{2}{|c|}{ Yield (g/plant) } & \multicolumn{2}{|c|}{ Clump Length $(\mathrm{cm})$} & \multicolumn{2}{|c|}{ Clump Breath $(\mathrm{cm})$} \\
\hline & $\mathbf{1}^{\text {st }} \mathbf{Y r}$ & $2^{\text {nd }} Y r$ & $1^{\text {st }} \mathrm{Yr}$ & $2^{\text {nd }} Y r$ & $1^{\text {st }} \mathbf{Y r}$ & $2^{\text {nd }} \mathrm{Yr}$ & $\mathbf{1}^{\text {st }} \mathbf{Y r}$ & $2^{\text {nd }} Y r$ \\
\hline $\mathbf{P}_{1} \mathbf{S}_{1}$ & 13.53 & 10.72 & 220.00 & 184.00 & 17.85 & 17.24 & 10.86 & 10.56 \\
\hline $\mathbf{P}_{1} \mathbf{S}_{2}$ & 13.95 & 11.04 & 230.66 & 193.00 & 19.99 & 18.72 & 12.56 & 12.43 \\
\hline $\mathbf{P}_{2} \mathbf{S}_{1}$ & 11.08 & 10.09 & 221.33 & 204.00 & 18.86 & 18.28 & 13.03 & 11.26 \\
\hline $\mathbf{P}_{2} \mathbf{S}_{2}$ & 11.68 & 10.36 & 238.33 & 216.33 & 19.56 & 18.33 & 13.20 & 12.50 \\
\hline $\mathbf{P}_{3} \mathbf{S}_{1}$ & 10.62 & 9.36 & 244.33 & 217.66 & 20.66 & 18.13 & 11.96 & 11.66 \\
\hline $\mathbf{P}_{3} \mathbf{S}_{2}$ & 11.44 & 10.10 & 260.00 & 243.33 & 21.73 & 20.14 & 13.73 & 12.20 \\
\hline $\mathbf{P}_{4} \mathbf{S}_{1}$ & 9.57 & 8.60 & 259.00 & 232.66 & 20.05 & 18.66 & 13.10 & 12.40 \\
\hline $\mathbf{P}_{4} \mathbf{S}_{2}$ & 10.96 & 9.52 & 301.00 & 268.00 & 22.42 & 21.05 & 14.20 & 12.96 \\
\hline $\mathbf{P}_{5} \mathbf{S}_{1}$ & 9.00 & 7.78 & 292.66 & 246.66 & 21.03 & 19.80 & 13.26 & 12.70 \\
\hline $\begin{array}{l}\mathbf{P}_{5} \mathbf{S}_{2} \\
\mathbf{P} \times \mathbf{S}\end{array}$ & 10.90 & 8.98 & 350.66 & 288.33 & 22.40 & 21.25 & 14.80 & 12.63 \\
\hline S.Em. $( \pm)$ & 1.323 & 1.198 & 17.619 & 10.790 & 0.899 & 1.319 & 0.562 & 0.778 \\
\hline $\mathrm{CD}(\mathrm{P}=\mathbf{0 . 0 5})$ & 4.168 & 3.774 & NS & NS & 2.831 & NS & 1.770 & NS \\
\hline
\end{tabular}


Table.3 Effect of different spacing and seed rate on finger of ginger

\begin{tabular}{|c|c|c|c|c|c|c|c|c|}
\hline \multirow{2}{*}{ Treatment } & \multicolumn{2}{|c|}{ Number } & \multicolumn{2}{|c|}{ Weight (g) } & \multicolumn{2}{|c|}{ Length $(\mathbf{c m})$} & \multicolumn{2}{|c|}{ Breadth $(\mathbf{c m})$} \\
\hline & $\mathbf{1}^{\text {st }} \mathbf{Y r}$ & $2^{\text {nd }} Y r$ & $1^{\text {st }} \mathbf{Y r}$ & $2^{\text {nd }} Y r$ & $\mathbf{1}^{\text {st }} \mathbf{Y r}$ & $2^{\text {nd }} Y r$ & $\mathbf{1}^{\text {st }} \mathbf{Y r}$ & $2^{\text {nd }} Y r$ \\
\hline$P_{1}(20 \times 15 \mathrm{~cm})$ & 5.93 & 4.99 & 61.32 & 51.51 & 9.57 & 9.35 & 2.39 & 2.29 \\
\hline$P_{2}(20 \times 20 \mathrm{~cm})$ & 6.16 & 5.36 & 59.38 & 54.30 & 9.78 & 9.10 & 2.54 & 2.47 \\
\hline$P_{3}(25 \times 20 \mathrm{~cm})$ & 4.26 & 6.0 & 64.03 & 55.27 & 9.96 & 9.38 & 2.76 & 2.68 \\
\hline$P_{4}(25 \times 25 \mathrm{~cm})$ & 6.43 & 6.43 & 67.94 & 57.63 & 10.70 & 10.07 & 2.79 & 2.75 \\
\hline$P_{5}(30 \times 25 \mathrm{~cm})$ & 6.39 & 5.81 & 69.62 & 60.18 & 10.75 & 10.68 & 2.99 & 2.89 \\
\hline S.Em. $( \pm)$ & 0.223 & 0.216 & 2.132 & 1.986 & 0.421 & 0.386 & 0.086 & 0.075 \\
\hline $\mathrm{CD}(\mathrm{P}=\mathbf{0 . 0 5})$ & 0.700 & 0.678 & 6.694 & 6.236 & 1.321 & 1.212 & 0.270 & 0.235 \\
\hline$S_{1}(20 \mathrm{~g})$ & 5.994 & 5.532 & 62.57 & 54.658 & 9.962 & 9.344 & 2.602 & 2.586 \\
\hline$S_{2}(30 \mathrm{~g})$ & 6.532 & 5.910 & 66.35 & 56.904 & 10.35 & 10.09 & 2.794 & 2.652 \\
\hline S.Em. $( \pm)$ & 0.148 & 0.143 & 1.613 & 1.121 & 0.213 & 0.198 & 0.102 & 0.092 \\
\hline $\mathrm{CD}(\mathrm{P}=\mathbf{0 . 0 5})$ & 0.464 & 0.449 & 5.064 & 3.519 & 0.759 & 0.684 & NS & NS \\
\hline
\end{tabular}

Table.4 Interaction different spacing and seed rate effect of on finger of ginger

\begin{tabular}{|c|c|c|c|c|c|c|c|c|}
\hline \multirow{2}{*}{ Treatment } & \multicolumn{2}{|c|}{ Number } & \multicolumn{2}{|c|}{ Weight (g) } & \multicolumn{2}{|c|}{ Length $(\mathbf{c m})$} & \multicolumn{2}{|c|}{ Breadth $(\mathrm{cm})$} \\
\hline & $1^{\text {st }} \mathbf{Y r}$ & $2^{\text {nd }} Y r$ & $1^{\text {st }} Y r$ & $2^{\text {nd }} Y r$ & $1^{\text {st }} \mathrm{Yr}$ & $2^{\text {nd }} Y r$ & $1^{\text {st }} \mathbf{Y r}$ & $2^{\text {nd }} Y r$ \\
\hline $\mathbf{P}_{1} \mathbf{S}_{1}$ & 5.66 & 4.93 & 60.1 & 48.81 & 9.30 & 9.21 & 2.21 & 2.13 \\
\hline $\mathbf{P}_{1} \mathbf{S}_{2}$ & 6.20 & 5.06 & 62.55 & 54.21 & 9.85 & 9.49 & 2.58 & 2.46 \\
\hline $\mathbf{P}_{2} \mathbf{S}_{1}$ & 5.93 & 5.13 & 56.22 & 53.68 & 9.42 & 8.44 & 2.40 & 2.49 \\
\hline $\mathbf{P}_{2} \mathbf{S}_{2}$ & 6.40 & 5.60 & 62.55 & 54.93 & 10.15 & 9.77 & 2.69 & 2.45 \\
\hline $\mathbf{P}_{3} \mathbf{S}_{1}$ & 6.26 & 5.80 & 62.36 & 54.80 & 9.81 & 8.77 & 2.67 & 2.64 \\
\hline $\mathbf{P}_{3} \mathbf{S}_{2}$ & 6.53 & 6.20 & 65.71 & 55.75 & 10.12 & 9.99 & 2.86 & 2.73 \\
\hline $\mathbf{P}_{4} \mathbf{S}_{1}$ & 6.06 & 6.00 & 66.42 & 56.75 & 10.43 & 9.60 & 2.75 & 2.75 \\
\hline $\mathbf{P}_{4} \mathbf{S}_{2}$ & 6.80 & 6.86 & 69.44 & 58.52 & 10.97 & 10.55 & 2.83 & 2.76 \\
\hline $\mathbf{P}_{5} \mathbf{S}_{1}$ & 6.06 & 5.80 & 67.73 & 59.25 & 10.85 & 10.70 & 2.98 & 2.92 \\
\hline $\begin{array}{l}\mathbf{P}_{5} \mathbf{S}_{2} \\
\mathbf{P} \times \mathbf{S}\end{array}$ & 6.73 & 5.83 & 71.51 & 61.11 & 10.66 & 10.66 & 3.01 & 2.86 \\
\hline S.Em.( $( \pm)$ & 0.214 & 0.196 & 0.972 & 2.131 & 0.257 & 0.261 & 0.116 & 0.096 \\
\hline $\mathrm{CD}(\mathrm{P}=0.05$ & 0.672 & 0.615 & 0.619 & 6.691 & 0.813 & 0.781 & NS & NS \\
\hline
\end{tabular}

Table.5 Effect of different spacing and seed rate on economics of ginger cultivation (Rs. /ha)

\begin{tabular}{|c|c|c|c|c|c|c|c|c|}
\hline \multirow{2}{*}{ Treatment } & \multicolumn{2}{|c|}{ Cost of cultivation } & \multicolumn{2}{|c|}{ Gross return } & \multicolumn{2}{|c|}{ Net return } & \multicolumn{2}{|c|}{ Benefit : Cost } \\
\hline & $\mathbf{1}^{\text {st }} \mathbf{Y r}$ & $2^{\text {nd }} Y r$ & $1^{\text {st }} \mathbf{Y r}$ & $2^{\text {nd }} \mathbf{Y r}$ & $1^{\text {st }} \mathbf{Y r}$ & $2^{\text {nd }} Y r$ & $1^{\text {st }} \mathbf{Y r}$ & $2^{\text {nd }} \mathbf{Y r}$ \\
\hline$P_{1}(20 \times 15 \mathrm{~cm})$ & 96,310 & 91,145 & 173,706 & 153,922 & 77,396 & 62,777 & 1.08 & 1.68 \\
\hline$P_{2}(20 \times 20 \mathrm{~cm})$ & 83,091 & 77,806 & 152,465 & 147,801 & 69,374 & 69,996 & 1.83 & 1.89 \\
\hline$P_{3}(25 \times 20 \mathrm{~cm})$ & 75,170 & 69,825 & 149,316 & 144,021 & 74,146 & 74,195 & 1.98 & 2.06 \\
\hline$P_{4}(25 \times 25 \mathrm{~cm})$ & 68,810 & 63,407 & 142,431 & 137,542 & 73,621 & 74,137 & 2.06 & 2.16 \\
\hline$P_{5}(30 \times 25 \mathrm{~cm})$ & 64,510 & 58,985 & 139,911 & 131,422 & 75,401 & 67,437 & 2.16 & 2.22 \\
\hline S.Em. $( \pm)$ & 6.992 & 7.124 & 1.614 & 3.056 & 5.583 & 8.216 & 0.01 & 0.05 \\
\hline $\mathrm{CD}(\mathrm{P}=\mathbf{0 . 0 5})$ & 22.801 & 23.231 & 5.263 & 9.967 & 18.207 & 26.792 & 0.03 & 0.15 \\
\hline$S_{1}(20-25 g)$ & 71,118 & 65,773 & 146,886 & 139,773 & 75,767 & 74,000 & 2.06 & 2.12 \\
\hline$S_{2}(30-35 g)$ & 84,038 & 78,693 & 156,246 & 146,109 & 72,208 & 67,416 & 1.85 & 1.85 \\
\hline S.Em. ( $( \pm)$ & 4.921 & 3.716 & 1.405 & 2.099 & 4.937 & 5.726 & 0.01 & $\mathbf{0 . 0 3}$ \\
\hline $\mathrm{CD}(\mathrm{P}=\mathbf{0 . 0 5})$ & 15.503 & 11.705 & 4.425 & 6.612 & 15.554 & 18.036 & $\mathbf{0 . 0 3}$ & 0.09 \\
\hline
\end{tabular}


Table.6 Interaction effect of different treatments on economics of ginger cultivation (Rs. /ha)

\begin{tabular}{|c|cc|cc|cc|cc|}
\hline \multirow{2}{*}{ Treatment } & \multicolumn{2}{|c|}{ Cost of cultivation } & \multicolumn{2}{c|}{ Gross return } & \multicolumn{2}{c|}{ Net return } & \multicolumn{2}{c|}{ Benefit : Cost } \\
\cline { 2 - 9 } & $\mathbf{1}^{\text {st }} \mathbf{Y} \mathbf{r}$ & $\mathbf{2}^{\text {nd }} \mathbf{Y r}$ & $\mathbf{1}^{\text {st }} \mathbf{Y r}$ & $\mathbf{2}^{\text {nd }} \mathbf{Y r}$ & $\mathbf{1}^{\text {st }} \mathbf{Y r}$ & $\mathbf{2}^{\text {nd }} \mathbf{Y r}$ & $\mathbf{1}^{\text {st }} \mathbf{Y r}$ & $\mathbf{2}^{\text {nd }} \mathbf{Y r}$ \\
\hline $\mathbf{P}_{\mathbf{1}} \mathbf{S}_{\mathbf{1}}$ & 86,310 & 81,145 & $1,71,816$ & $1,52,482$ & 85,506 & 71,337 & 1.99 & 1.87 \\
$\mathbf{P}_{\mathbf{1}} \mathbf{S}_{\mathbf{2}}$ & $1,06,312$ & $1,01,146$ & $1,75,597$ & $1,55,362$ & 69,285 & 54,216 & 1.02 & 1.53 \\
$\mathbf{P}_{\mathbf{2}} \mathbf{S}_{\mathbf{1}}$ & 75,593 & 70,305 & $1,49,766$ & $1,46,362$ & 74,172 & 76,057 & 1.98 & 2.08 \\
$\mathbf{P}_{\mathbf{2}} \mathbf{S}_{\mathbf{2}}$ & 90,590 & 85,304 & $1,55,165$ & $1,49,241$ & 64,575 & 63,936 & 1.71 & 1.74 \\
$\mathbf{P}_{\mathbf{3}} \mathbf{S}_{\mathbf{1}}$ & 69,171 & 63,825 & $1,45,626$ & $1,40,600$ & 76,456 & 76,775 & 2.10 & 2.20 \\
$\mathbf{P}_{\mathbf{3}} \mathbf{S}_{\mathbf{2}}$ & 81,173 & 75,825 & $1,53,005$ & $1,47,442$ & 71,837 & 71,617 & 1.88 & 1.94 \\
$\mathbf{P}_{\mathbf{4}} \mathbf{S}_{\mathbf{1}}$ & 64,010 & 58,606 & $1,36,176$ & $1,33,403$ & 72,166 & 74,795 & 2.12 & 2.27 \\
$\mathbf{P}_{\mathbf{4}} \mathbf{S}_{\mathbf{2}}$ & 73,614 & 68,207 & $1,48,684$ & $1,41,682$ & 75,076 & 73,477 & 2.01 & 2.07 \\
$\mathbf{P}_{\mathbf{5}} \mathbf{S}_{\mathbf{1}}$ & 60,510 & 54,985 & $1,31,046$ & $1,26,024$ & 70,536 & 71,037 & 2.16 & 2.29 \\
$\mathbf{P}_{\mathbf{5}} \mathbf{S}_{\mathbf{2}}$ & 68,512 & 62,985 & $1,48,776$ & $1,36,822$ & 80,266 & 73,837 & 2.17 & 2.17 \\
$\mathbf{P} \mathbf{X}$ & & & & & & & & \\
\hline $\mathbf{S . E m} \mathbf{S}$. & $\mathbf{1 1 . 0 0 5}$ & $\mathbf{8 . 2 1 6}$ & $\mathbf{3 . 2 0 4}$ & $\mathbf{4 . 6 9 5}$ & $\mathbf{1 1 . 0 4 1}$ & $\mathbf{1 1 . 4 0 6}$ & $\mathbf{0 . 0 3}$ & $\mathbf{0 . 0 7}$ \\
$\mathbf{C D}(\mathbf{P}=\mathbf{0 . 0 5})$ & $\mathbf{3 4 . 6 6 5}$ & $\mathbf{2 5 . 8 8 0}$ & $\mathbf{1 0 . 0 9 2}$ & $\mathbf{1 4 . 7 8 9}$ & $\mathbf{3 4 . 7 8 0}$ & $\mathbf{3 5 . 9 2 5}$ & $\mathbf{0 . 0 9}$ & $\mathbf{0 . 2 2}$ \\
\hline
\end{tabular}

The data presented in table 1 revealed that yield per hectare of ginger was maximum with closer spacing in both the years. The increase in spacing from $20 \mathrm{x} 15 \mathrm{~cm}$ to $30 \mathrm{x}$ $25 \mathrm{~cm}$ showed a decreasing trend in total yield. Maximum yield of $13.74 \mathrm{t}, 10.88 \mathrm{t}$ were obtained under closest spacing $(20 \times 15$ $\mathrm{cm})$ in the respective years. The plant raised from bigger seed rhizome (30 g) recorded the higher yield of $11.78 \mathrm{t}$ and $10.00 \mathrm{t}$ per hectare in the respective years as compared to $10.76 \mathrm{t}$ and $9.31 \mathrm{t}$ from smaller seed rhizome (20 g).In case of interaction effect, closest spacing $(20 \times 15 \mathrm{~cm})$ in combination with bigger seed rhizome $(30 \mathrm{~g})$ produced highest yield of $13.95 \mathrm{t}$ and $11.04 \mathrm{t}$ as compared to minimum yield of $9.00 \mathrm{t}$ and $7.78 \mathrm{t}$ with widest spacing $(30 \times 25 \mathrm{~cm})$ in combination with smaller seed rhizome $(20 \mathrm{~g})$ in the respective years.

The results are in good agreement with Korla et al., (1989) and Randhwa et al., (1972) and Pandey (1999) reported that closer spacing was optimum for getting maximum yield in mango-ginger and kacholam (Family Zingiberaceae) respectively. The reduction in yield attributes under narrower spacing might be ascribed due to comparatively poor growth and development of individual plants owing to competition for growth resource like space, sun-light, nutrients, moisture etc. which is supported by the earlier findings (Singh et al., 2000; Mohanty et al., 1993).

The cost cultivation, gross return and net return decreased significantly with the increase in spacing (Table 5) decrease of plant population per unit area. It was observed that maximum cost of cultivation were recorded (Rs. 1,06,312/-) and (Rs. 101146/-) in both the year respectively with $20 \times 15 \mathrm{~cm}$ spacing and $30 \mathrm{~g}$ seed size. The gross return (Rs. 175,597/-and Rs $155,362)$ were also highest with this treatment (Table 6). The benefit: cost ratio was highest in $\mathrm{P}_{5} \mathrm{~S}_{1}$ (2.16 and2.29) followed by $\mathrm{P}_{4} \mathrm{~S}_{1}(2.12$ and 2.27) in the respective years.

It may be concluded that yield maximization and income enhancement point of view in interaction effect, closest spacing (20 x 15 $\mathrm{cm}$ ) in combination with bigger seed rhizome $(30 \mathrm{~g})$ produced highest yield of $13.95 \mathrm{t}$ and $11.04 \mathrm{t} / \mathrm{ha}$, also the highest income of Rs. 175597/-and Rs 155362 during 2013-14 and 2014-15 respectively. These may be suggested as the most effective cultivation option in the Alluvial zone of West Bengal.

\section{Acknowledgement}

This is a short term work carried out for 7 month in both the year of 2013-14 and 2014- 
15 and fund for this research work received from Bidhan Chandra Krishi Viswavidyalaya has been duly acknowledged.

\section{References}

Ghosh, D.K., and Bandopadhyay, A. 2008. Effect of different spacing of French bean (Phaseolus vuelgaris L) on its growth and yield grown as intercrop with coconut. Indian Coconut Journal. 38(12): 19-22.

Ghosh, D.K., Hore, J.K., Bandopadhyay, A. and Maji. M.K. 2008. Effect of spacing and seed corm size and of elephant foot yam on economics of a coconut based cropping system. Journal of Crop and Weed. 4(1): 15-19.

Ghosh, D.K., Hore, J.K., Bandopadhyay, A. 2008. Standardization of spacing and size of planting material of elephant foot-yam grown as intercrop in coconut plantation. Indian Journal of Horticulture. 65(1): 44-47.

Korla, B.N., Rattan, R.S. and Dohroo, N.P. 1989. Effect of seed rhizome size on growth and yield in ginger. Indian Cocoa Arecanut and Spices Journal. 13(2): 47-48.

Mohanti, D.C., Sarma, Y.N., Naik, B.S. and
Panda, B.S. 1988. Influence of fertilizer cum seed rate on yield and performance of selected ginger clones in the Eastern Ghat Highland Zone of Orissa. Indian Cocoa Arecanut and Spices Journal. 12(1): 1-3.

Mohanti, D.C., Sarma, Y.N., Panda, B.S. and Edison, S. 1993. Studies on fertilizer management and seed rates in ginger vatiety suruchi. Indian Cocoa Arecanut and Spices Journal. 16(3-4): 101-104.

Pandey, A.K., 1999. Response of mango ginger to nitrogen and plant spacing under terrace system of cultivation in mid altitude areas of Mizoram. Journal of Hill Agriculture. 12(1): 77-78.

Randhawa, K.S., Nandpuri, K.S. and Bajiva, M.S. 1972. A study on comparative efficacy of different sizes of seed and spacing on the yield of ginger (Zingiber officinale Rosc.). J. Research - Birsa Agricultural University, Ranchi 9(2): 239-241.

Singh, J., Malik, Y.S., Nehra, B.K. and Partap, P.S. 2000. Effect of size of seed rhizomes and plant spacing on growth and yield of turmeric (Curcuma longa L.). Haryana Journal of Horticultural Science. 29(3 \& 4): 258-260.

\section{How to cite this article:}

Nilanjana Datta, D.K. Ghosh and Tapas Sarkar. 2017. Effect of Different Seed Rate and Spacing on Yield and Economics of Ginger (Zingiber officinale Rosc) Cultivation. Int.J.Curr.Microbiol.App.Sci. 6(9): 1120-1125. doi: https://doi.org/10.20546/ijcmas.2017.609.134 